İŞLETME ARAŞTIRMALARI DERGİSI
JOURNAL OF BUSINESS RESEARCH-TURK
2021, 13(2), 1255-1272
https://doi.org/10.20491/isarder.2021.1197

\title{
Kurum İçi İletişimin Kurumsal Bağlılık Üzerine Etkisi ve Bir Kamu Kurumu Uygulaması (The Effect of Internal Corporate Communication on the Organizational Commitment and Application of the Public Institution)
}

\section{Feriha BULUT iD a Metehan TOLON iD $b$}

a Türkiye Cumhuriyet Merkez Bankası, Ankara, Türkiye. feriha.bulut@tcmb.gov.tr

b Ankara Hacı Bayram Veli Üniversitesi, İktisadi ve İdari Bilimler Fakültesi, Ankara, Türkiye. metehan.tolon@hbv.edu.tr

\begin{tabular}{|c|c|}
\hline MAKALE BİLGİSİ & ZET \\
\hline Ana & aç -Kurumların hedef ve stratejilerini \\
\hline $\begin{array}{l}\text { Kurumsal Bağl1lık } \\
\text { Bağlılık } \\
\text { Kurum İçi İletişim }\end{array}$ & $\begin{array}{l}\text { çalışan odaklı yönetim anlayışıyla bağlılığ } \text { yüksek çalışanları istihdam etmeye yönelik politikalar } \\
\text { zlemektedir. Çalışan bağlı̆ı̆̆nı yükseltmek ve bu çalışanların kurumda çalışmaya devam etmelerini } \\
\text { sağlamak için etkin bir iç iletişim politikasının sürdürülmesi gerekmektedir. Bu araştırma, bir kamu }\end{array}$ \\
\hline Gönderilme Tarihi 3 Mart & rumundakurum içi iletişimin, kurumsal bağlılık üzerindeki etkisini belirlemek amacıyla yapılmıştır. \\
\hline 2021 & Inket kullanılmistır A rastırmanın ovrenini 374 \\
\hline Revizy & luşturmaktadır. Ç \\
\hline 2021 & sis homoien ol \\
\hline Kabul Tarihi 5 Haziran & ılmış ve örneklem büyüklüğünün en az n = 349 kişi olma \\
\hline 2021 & $\begin{array}{l}\text { online bir sistem üzerinden uygulanan anket için evrenden örneklem seçilmemiş, kişilere e-posta ile anketin } \\
\text { linki gönderilerek gönüllü katılımla evrenin kendini örneklemesi hedeflenmiştir. Sonuçta } 652 \text { kişi anketi }\end{array}$ \\
\hline & tam olarak doldurmuş, araştırma sonuçlarının $\% 95$ güven aralığında ve $\pm \% 5$ örnekleme hatası i \\
\hline Araştı & $\begin{array}{l}\text { nelleyebileceği yeterli örneklem hacmine ulaşılmıştır. Elde edilen veriler analiz edilirken ise SPSS } 20.0 \\
\text { atistik programı kullanılmıştır. }\end{array}$ \\
\hline
\end{tabular}

Bulgular -Araştırma sonucunda kurum içi iletişim unsurlarının kamu kurumlarında da çalışan bağlılığını artırmada önemli bir politka aracı olduğu bulgusuna ulaşılmıştır.

Tartışma -Araştırma sonucunda kurum içi iletişimin kurumsal bağlılık üzerindeki etkisi göz önüne alınarak, iç iletişim politikalarına yönelik olarak İnsan Kaynakları yönetiminde neler yapılabileceğine ilişkin öneriler sunulmuştur.

\begin{tabular}{l} 
ARTICLE INFO \\
\hline Keywords: \\
Organizational \\
commitment \\
Commitment \\
Internal communication
\end{tabular}

\section{ABSTRACT}

Purpose -The most important tool for institutions to achieve their goals and strategies, is the human resource with high corporate commitment that has adopted these goals and strategies.Therefore, today's human resources management follows policies aimed at employing highly committed employees with an employee-oriented management approach. To enhance commitment of employees and provide them to continue to work at the organization, an effective internal communication policy needs to be maintained. This research was conducted to determine the effect of internal communication in a public institution on corporate commitment.

Received 3 March 2021

Revised 16 May 2021

Accepted 5 June 2021

Design/methodology/approach - Questionnaire was used as a measurement tool in the study. The population of the research is 3743 corporate employees. Various title groups were not included as they were outside the scope of the study. For this non-homogeneous population, it was determined that the sample size should be at least $n=349$ people by calculating with $\pm 5 \%$ sampling error at $95 \%$ confidence interval.

Article Classification: Research Article For the questionnaire applied via an online system in electronic environment, no sample was selected from the universe, it was aimed to sample the universe with voluntary participation by sending the link of the questionnaire via e-mail. In this way, 652 people filled out the questionnaire completely, and a sufficient sample size was obtained that the research findings could generalize with a $95 \%$ confidence interval and \pm $5 \%$ sampling error. SPSS 20.0 statistics program was used to analyze the data.

Findings - As a result of the research, it was found that internal communication elements are an important policy tool in increasing employee engagement in public institutions.

Discussion - Considering the impact of internal communication on corporate commitment, suggestions were made on what can be done in Human Resources management for internal communication policies. 


\section{Giriş}

Tarihsel süreçte en önemli kırılmalardan biri olan Sanayi Devrimi'ne kadar üretime odaklanan bir çalışma sistemi hâkimdi. Ancak Sanayi Devrimi'nin ilk dönemlerinden itibaren bu çalışma şekli değişmeye başlamıştır. Bu değişen çalışma şekliyle birlikte çalışana sadece "personel" olarak bakan insan kaynakları yönetiminin hedef ve stratejilerin başarmasında başarısız olduğu günümüzde genel kabul gören bir durumdur. Bu nedenle, uzun süredir insan odaklı insan kaynakları yönetimi pek çok kurumda uygulanmaya çalışılmaktadır. İnsan odaklı yaklaşım bir tercih değil zorunluluk olarak kabul edilmektedir. Bu yaklaşım ise çalışan bağlılı̆̆ı, iletişim, çalışanın motivasyonu, performans ve ödüllendirme gibi kriterlerin sağlanmasıyla mümkün olmaktadır. Tüm bunlar ise doğrudan kurum içi iletişim ile ilgilidir.

Kurum içi iletişim; bunun önemini kabul eden yönetimin, üst yönetimin öncülüğünde planlanlanmayı ve yönetilmeyi gerektirecek kadar zaruri bir konu olarak ele alınmaktadır. Özellikle büyük kurumların yönetim biçimlerinde, liderlerin yaklaşımları iç iletişimde temel taşlardandır (Gürel, 2009, s. 23). Kurum içi iletişim, bir kurumun sinir sistemi gibidir (Değer, 2018).

Kurum içi iletişim, hiyerarşik yönetim sisteminin getirebileceği olumsuzluklar sonucu çalışanların memnuniyeti ve motivasyonu için önemlidir. Çalışanların gerek kendi aralarındaki iletişimleri gerekse üst yöneticileriyle olan iletişimleri için kurum içi iletişimin etkin olarak kullanılması gerekmektedir.

Kurumun hedef ve stratejilerini belirledikten sonra çalışanların bu konu hakkında bilgilendirilmesive bunun da ötesinde alınan kararlar konusunda çalışanların görüşlerine yer verilmesi, çalışanların kişisel gelişimleri için gereken eğitim imkân ve olanaklarının sunulması, iyi bir çalışma ortamının oluşturularak kurum içerisinde birlik bilincine yer verilmesi ve her bir çalışanın birey olarak kurum içerisinde ne kadar önemli olduğun hissiyatının kurum tarafından çalışanına hissettirilmesi kurum içi iletişimde olması gerekenbaşlıca konulardır. Tüm bunların olmasıkurumda çalışan motivasyonunu ve bağlılığını arttıracaktır.

$\mathrm{Bu}$ araştırma ile araştırma kapsamında elde edilen verilerin kurumda yöneticilerden çalışanlara kadar bilgi sağlanması, kurumsal bağlılığı arttırmak için iç iletişim aracılığıyla neler yapılabileceği konusunda fikirlerin paylaşılması amaçlanmıştır.

\section{Kavramsal Çerçeve}

\subsection{Kurumsal Bağlılık Kavramına Yönelik Kavramsal Çerçeve}

Kurumsal bağlllık ile ilgili ilk tanımlardan birini yapan Grusky, kurumsal bağlllı̆̆ "kişinin bir bütün olarak içinde bulunduğu sistem ile ilişkisinin niteliği" olarak tanımlamıştır (Grusky, 1996, s.488-503). Hunt ve Morgan ise "çalışanların kurumsal hedef ve amaçları gönülden kabul etmeleri, kurumun başarısı için çok çalışmaları ve kurumun sürekli üyesi olarak kalmaya istekli olmaları" olarak tanımlamıştır (Hunt ve Morgan, 1994, s.1568-1587).

Kurumsal bağlllık ile ilgili kabul gören en yaygın tanımlamalardan birisi Mowday, Porter ve Steers tarafından yapılmıştır. Tanımlarına göre "kurumsal bağllık bireylerin kurumsal amaç ve değerler doğrultusunda çaba gösterdiklerinde ve kurumla kendilerini özdeşleştirdiklerinde ortaya çıkmaktadır" (Mowday, Porter ve Steers, 2013). Kurumsal bağlılık ile ilgili pek çok tanım incelendiğinde temel çerçeveçalışanın kurumuna karşı psikolojik bağlılığı yönünde görülmekte, bir çalışanın, kurumunun amaç ve değerlerine taraflı ve etkili bağlılığı olarak tanımlanmaktadır. Bir çalışanın kurumuna olan bağllığının üç değişik şekilde ifadesi genel olarak kabul edilmiştir. Bunlar duygusal, devam ve değer (normatif) bağlllıklarıdır. Duygusal bağlılık, çalışanın kurumuna karşı duygusal bağlılığına işaret eder. Devam bağlılığı ise çalışanın, işten ayrılmanın maliyeti üzerine inşa ettiği kurumsal bağlılığıdır. Bu durumda çalışan yeni bir iş aramanın maliyetinin daha fazla olacağını düşündüğü için kurumda kalmaya devam eder. Son olarak değer bağlılığı diğer bir deyişle normatif bağlılık, çalışanın ahlaki bir sorumluluk olarak kurumda çalışmaya devam etmek istemesini ifade eder. Bu durum, çalışanın kurumunun kendine iyi davrandığını düşünmesi ve bunun karşılığında kuruma hizmet verme sorumluluğu hissetmesinden kaynaklanır (Çetin, 2004).

\subsection{Kurumsal Bağlılık Yaklaşımları}

Kurumsal bağlılık kavramının tanımlanmasında yaşanılan güçlükler, bağlılık kavramının başka diğer kavramlarla karıştırılması, bu kavramın sınıflandırılmasında da görülmektedir. Farklı araştırmacıların farklı 
kriterlerin varlığını savunması, sınıflandırmada da farklı yaklaşımların ortaya çıkmasına neden olmaktadır. Örneğin; Huang (2000) bağllıkla ilgili olarak geliştirilen teorileri dört farklı grupta sinıflandırmıştır: Davranışsal, sosyolojik, moral ve tutumsal bağlllık (Gül, 2002, s. 37-56).

Kurumsal bağlılığa ilişkin birbirinden farklı sınıflandırmalar yapmak mümkünse de literatürde üç sınıflandırma türü ön plana çıkmaktadır:

- Tutumsal bağlılık (Kanter'in Yaklaşımı, Etzioni'nin Yaklaşımı, O'Reilly ve Chatman Yaklaşımı, Penley ve Gould Yaklaşımı, Allen ve Meyer Yaklaşımı)

- Davranışsal bağlılık (Becker'ın Yan Bahis Yaklaşımı, Salancik Yaklaşımı)

- Çoklu bağllik

Kurumsal bağlılı̆̆ın tutumsal ve davranışsal olarak iki farklı şekilde incelenmesinin sebebi, kurumsal davranışçıların ve sosyal psikologların konuya farklı açlardan yaklaşmış olmalarıdır. Kurumsal davranışçılar tutumsal bağlllık üzerinde yoğun olarak dururken, sosyal psikologlar daha çok davranışsal bağlılık üzerinde durmuşlardır (Mowday, Porter ve Steers, 1982, s.24).

\subsubsection{Tutumsal Bağlılık Yaklaşımları}

Tutumsal bağlılık yaklaşımına göre bağlılık, kişinin çalışma ortamıyla ilgili değerlendirmeleri sonucunda oluşan ve onu kurumuna bağlayan duygusal bir tepkidir. Başka bir deyişle tutumsal bağlılık çalışanların kurumlarıyla olan ilişkilerini ifade eder. Bu bağlılık türünde çalışanın kendi değer ve hedeflerinin, kurumun değer ve hedefleriyle uyumlu olması gerekmektedir (Meyer ve Allen, 1997). Buchanan'a göre ise, tutumsal bağlllık üç bileşenlidir (Çöl, 2004).

Bu bileşenler;

- Kurumun amaç ve değerleri ile özdeşleşme,

- İşle ilgili faaliyetlere yüksek katılım,

- Kuruma sadakatle bağlanma'dır.

Bir çalışanın kurumuyla arasındaki ilişkiye yönelik tutumları, belli davranışlarda bulunmasına veya bu davranışlara eğilimli olmasına neden olacaktır (Gündoğan, 2009, s.42). Bu tür bağlllık, genellikle çalışanın kurumuyla özdeşleşmesinin ve kuruma katılımının gücü olarak ifade edilmektedir. Çalışan kurumun amaç ve hedeflerini kabul eder ve kendine uyarlar, diğer bir ifadeyle içselleştirir (Lam ve T. ve Zhang, 2003, s.214220).

Tutumsal bağlılık ile ilgili yazında bu bağlılık türüne ilişkin farklı yaklaşımlar olduğu görülmektedir. Bu yaklaşımlardan bu çalışmada kullanılan Allen ve Meyer Yaklaşımı'na aşağıda yer verilmiştir.

\subsubsection{Allen ve Meyer Yaklaşımı}

Allen ve Meyer'in tanımlarına göre tutumsal bağlılık, çalışanların kurumla olan ilişkilerinin psikolojik boyutudur. Bu durum, çalışanların tutum ve davranışlarıyla açıklanmaktadır. Bağlılığın göstergesi, çalışanın kurumda kalmaya devam etmesidir (Allen ve Meyer, 1993, s. 46-91). Allen ve Meyer, kurumsal bağlllığın üç unsurdan oluştuğunu belirtmektedir. Bunlar; duygusal (affactive) bağlllık, devamlılık (continuance) bağllı̆̆ı ve normatif bağlllıktır. Bunun yanında Meyer ve diğerlerine göre nedensel sıralama konusunda bir fikir birliği olmadığından dolayı bağlılık ilişkilerinin de değerlendirilmesi önem taşımaktadır. Nedensellik konusundaki tartışmalar, özellikle iş tatmini konusunda önem kazanmaktadır. İşe katılım ve mesleki bağlllık da sık incelenen diğer korelasyonlardır. İş tatmini gibi, bu değişkenlerin de "duygusal" bir tonu vardır ve en iyi olarak duygusal bağlılı̆̆ın korelasyonları olarak kabul edilir.

Ancak Meyer ve Allen (1991, 1997), birbirleriyle ilişkili olmalarına rağmen, iş tatmini, işe katılım ve mesleki bağllı̆̆ın kuruma olan duygusal bağlllıktan ayırt edilebileceğini savunmaktadır (Meyer, Stanley, Herscovitch ve Topolnytsky, 2002, s. 20-52).

Duygusal bağ lllık, kurum çalışanlarının amaç ve değerleri içselleştirmesini ve kurum yararına olağanüstü çaba sarf etmesini tanımlamaktadır (McGee ve Ford, 1987, s. 638). Meyer ve Allen (1991, s.61-89), duygusal bağlılıkla ilişkinin tutarlı ve güçlü olmasının, iş deneyimleriyle ilgili olduğunu vurgulamaktadır. Çalışanların kuruma ilişkin deneyimleri beklentileri sonucunda oluşmaktadır. Buna ek olarak çalışanlar, mevcut 
ihtiyaçlarını karşılamak için daha az tatmin edici deneyimlerden çok, kuruma daha güçlü duygusal bağlılık geliştirmelerini sağlayıcak deneyimlere eğilimlidirler (Yıldırım, 2007, s. 253-278).

Duygusal bağlılık, literatürde en çok ele alınan bağlllık türüdür. Allen ve Meyer, bu bağlılık türünü, çalışanın kendisini kurumun bir parçası olarak görmesi sonucu oluştuğu için çok önemli görmektedir. Güçlü duygusal bağllı̆̆ı olan çalışanlar, kurumda kalmakta ve kurumun amaç ve değerlerini kabullenmektedir (İnce ve Gül, 2005). Duygusal bağlılığı yüksek olan çalışanlar, kurumda çalışmaya devam etme gerekçesi olarak kurumun hedeflerine ulaşmasında yardımcı olmayı istediklerini belirtir. Ekonomik gerekçeler geri plandadır. Bu durumda kurumun performansı ön planda olup çalışan kurumun başarı ve başarısızlığını kendisininmiş gibi kabul etmektedir (Gül, 2003, s. 73-83).

Allen ve Meyer (1990, s.17-18), duygusal bağl1lı̆̆ etkileyen faktörleri şu şekilde sıralamıştır:

- İşin zorluğu: Kurumda yapılan işin çalışan tarafından zor ve çabalamasını gerektiren bir iş olması.

- İş tanımı: Çalışandan beklenilenin açıkça ortaya konması.

- Amacın açılığı: Çalışanların, kurumda yaptıkları işlerin nedenlerini açıkça biliyor olması.

- Amacın zorluğu: Çalışanın yaptığı işin, özel bir sebep nedeniyle zorlayıcılığa sahip olmaması.

- Yönetimin önerilere açık olması: Kıdem olarak yüksek yöneticilerin, astlardan gelen her türlü öneriye açık olmasi.

- İş arkadaşlarıyla uyum: Kurum çalışanları arasında uyum ve samimiyet olması.

- Kurumsal adalet: Kurumda iş dağılımlarının adaletli yapılması.

- Eşitlik: Kurumda çalışanların hak ettiklerini elde etmesi.

- Kişisel önem: Çalışanın yaptığı işin kurum tarafından desteklenmesi ve önemsenmesi.

- Geri bildirim: Çalışana performansı ile ilgili değerlendirmede bulunulması.

- Katılım: Çalışanın, kurumla ilgili kararlara dâhil edilmesi.

Devamlılık bağgllığı, Becker'ın 1960 yılında yaptığı Side-Bets çalışmasından yola çıkarak tanımladıkları bağlılık türüdür. Akademik yazında, "rasyonel bağllılı" ya da "algılanan maliyet" olarak da kullanılan devamlılık bağlılığı, çalışanın kurumu bırakmasının getireceği maliyetleri düşünerek adım atması anlamına gelmektedir (Chen ve Francesco, 2003, s. 490-510).

Devamlılık bağlılığı, kurumdan ayrılmanın getireceği yüksek maliyetlerden dolayı çalışanın o kurumda kalma zorunluluğu hissetmesini ifade etmektedir. Bu maliyetler iki unsurdan oluşmaktadır. Birincisi, çalışanların belirli bir kurumda çalıştıkları süre ne kadar uzun olursa, kurumdan ayrılmaya karar verme durumunda vazgeçilecek kişisel yatırımlar da (emeklilik için yapılan pirim ödemeleri, ödüller, vb.) o ölçüde fazla olmaktadır. İkincisi ise, alternatif iş olanakları konusunda yaşanan sıkıntılardır. Böyle bir durumda çalışanların bağlılığı daha yüksek olacaktır (Allen ve Meyer, 1990, s.4). Bunun sonucunda, çalışan gönüllü olmasa da bu maliyetlere katlanmamak için kurumunda çalışmaya devam edecektir.

Meyer ve arkadaşları devamlılık bağlılığı yüksek olan çalışanların performanslarının düşük olduğunu veya en azından yüksek performansa sahip olmadıklarını belirtmektedirler (Meyer, Paunonen, Gellatly, Goffin ve Jackson, 1989, s.152).

Allen ve Meyer (1990, s. 18), devamlılık bağlılığına etki eden faktörleri şu şekilde sıralamıştır:

- Beceriler: Çalışanların sahip olduğu yetenek ve deneyimleri, bir başka kuruma transfer edebilme durumu.

- Eğitim: Çalışanın sahip olduğu eğitimin başka bir kuruma yararlı olup olmaması.

- Yer değiştirebilme: Çalışanın, başka bir kurumda farklı lokasyonda çalışıp çalışamayacağı.

- Kişisel yatırım: Çalışanın zamanın büyük bir kısmını kendine değil çalıştı̆̆ı kuruma vermesi.

- Emeklilik maaşı: Çalışanın kurumundan ayrılması durumunda emeklilik için ödediği primleri kaybetme endişesi.

- Bulunulan çevre: Çalışanın ne kadar süredir aynı çevrede olduğu.

- Alternatifler: Çalışanın kurumdan ayrılması durumunda iş alternatiflerinin varlığı.

Normatif bağhllık, çalışanların ahlaki bir görev duygusuyla davranarak, kurumdan ayrılmamaları gerektiği inancına sahip olmaları olarak tanımlanmaktadır (Özdevecioğlu, 2013, s. 113-130).

Normatif bağlılık, çalışanın kurumda kalmasının bir sadakat göstergesi olacağını öne çıkaran sosyalleşme tecrübelerinin sonucunda gelişmektedir (Allen ve Meyer 1990, s.1-18; Meyer ve Allen, 1984, s.372-378; Meyer 
ve diğerleri, 1993, s.538-555). Bu bağlılık türü, bir "zorunluluk" kaynaklıdır. Çalışanların bağlılık duymaları gönüllü olarak değil, bu şekilde davranmanın doğru ve ahlaki olduğunu düşünmelerinden kaynaklanmaktadır. Normatif bağlılık, çalışanların sosyal çevrelerinden baskı hissetmeleri sonucu ortaya çıkmaktadır (Powell ve Meyer, 2004, s. 157-177). Allen ve Meyer (1990, s.18), normatif bağlılığın çalışanın karakteristik özellikleri, kişisel yaşantıları, kültür ve sosyalleşme süreçlerinden etkilendiğini belirtmektedirler.

Allen ve Meyer'ın açıkladığı üç bileşenli bağlılık modelinde, her üç bağlılık türü de işten ayrılma oranlarıyla negatif ilişkilidir. Ancak, çalışanların iş başındaki davranışları ve performansları özelinde bakıldığında bu üç bağllılı türü ile bu iki unsurun arasındaki ilişkide farklılıklar olabileceği belirtilmektedir. Özellikle, duygusal bağlllığın ve bir şekilde daha az ölçüde normatif bağlılığın, iş performansı ve kurumsal vatandaşlık ile olumlu bir ilişki içinde olmasını beklediklerini ileri sürülmektedir. Diğer yandan devam bağlılığının ise iş performansı ve kurumsal vatandaşlık ile ilişkisiz ya da negatif yönlü bir ilişki içerdiğini belirtilmektedir. Bu nedenle, tüm bağlılık biçimlerinin birbirine benzemediğini ve bağlılıklarını güçlendirerek çalışanları korumakla ilgilenen kurumların bu farklılıkları göz önünde bulunması gerektiği söylenmektedir (Blau, 1985, s. 277-288).

\subsection{2. Çoklu Bağlılık Yaklaşımları}

Kurumsal bağlılık, çalışanların kurumlardaki iş davranışlarını anlamada kullanılan önemli bir değişken olarak bilinmektedir. Reichers (1985) çalışmasında, tutumsal bağlılık yaklaşımını geliştirerek, çoklu bağllık yaklaşımını geliştirmiştir (Reichers, 1985, s. 465-476). Reichers'a göre, kurumsal bağlılık ilk olarak psikolojik bağlılık olarak algılanmaktadır. Psikolojik bağlılık da devamlılık bağlılığının ilk adımı olarak ele alınmaktadır. Ancak, sonrasında çalışanların kurumlarına bağlılıklarının kişisel yatırım, ücret, kıdem ve alternatif fırsatların olmayışı gibi yapısal faktörlerdeki değişikliklerden ortaya çıkabileceği belirtilmektedir (Gül, 2002, s. 37-56).

Reichers'e (1985) göre diğer bağllık yaklaşımlarında kurum, çalışan için tek bir varlığı simgelemektedir. Ancak, Reichers çalışmasında bunun doğru olmadığını, kurum tanımlamalarının farklı amaç ve değerler bütününe sahip olduğu birlikleri içerdiğini belirtmektedir. Bu doğrultuda çoklu bağlılık yaklaşımı, kurum içinde bulunan farklı unsurlara bağlı olarak farklı düzeylerde bağlılık türlerinin ortaya çıkabileceğini savunduğundan diğer iki bağlllık türünden ayrı olarak incelenmektedir (Balay, 2000, s.24-26).

Çoklu bağlılık yaklaşımı, çalışanların kurumlarına, mesleklerine, yöneticilerine ve is arkadaşlarına farklı düzeylerde bağlllık göstereceklerini ileri sürmektedir (Becker, Billings, Eveleth ve Gilbert, 1996, s. 464-482). Dolayısıyla, bir çalışan tarafından duyulan bağlılığın bir başka çalışan tarafından duyulan bağlılıktan farklı olabileceğini öngörmektedir.

\subsubsection{Davranışsal Bağlılık Yaklaşımları}

Davranışsal bağlılık, çalışan bağlılığının dışavurumudur. Diğer bir ifadeyle normatif beklentileri aşan davranışlar bütünüdür. Davranışsal bağlılık kavramı, çalışanın geçmişteki davranışlarından dolayı kurumunda kalmak istemesi ile ilgilidir (Mowday, Porter ve Steers, 2013).

Çalışanın kurumda kalmak istemesi ile anlatılmak istenilen, çalışanın kurumda kalma niyetine sahip olması, kurumundan ayrılmaması veya işe devamlılı̆̆ının olmasıdır (DeCotiis ve Summers, 1987, s. 445-470).

Meyer ve Allen, davranışsal bağlılı̆̆ı çalışanın kurumlarında çok uzun süre kalmalarını sorun olarak görmeleri ve bu sorunla nasıl başa çıkmaları gerektiği konusu ile açıklamaktadır. Dolayısıyla, davranışsal bağlılık, çalışanın kurumundan daha çok kendi davranışlarına karşı geliştirdiği bir tutumdur. Çalışanın, belli bir davranışta bulunmaya başladıktan sonra bu davranışlarını devam ettirmesidir. Kendi davranışlarına bu şekilde bir bağlılık geliştiren çalışan bu davranışlarına uygun tutumlar geliştirir. Bu tutumlar da davranışların tekrar edilme sıklığını arttırmaktadır (Meyer ve Allen, 1990, s.61-89).

\subsection{Kurum İçi İletişim Kavramına Yönelik Kavramsal Çerçeve}

Tarihsel süreç incelendiğinde kurum içi iletişim; 1940'lı yıllarda "çalışanları eğlendirme", 1950'li yıllarda "çalışanları bilgilendirme", 1960'lı yıllarda "çalışanları ikna etme", 70 ve 80'li yıllarda "açık iletişim" ve 1990'lı yıllarda "çalışan memnuniyeti" olarak karşımıza çıkmaktadır. 2000'li yıllardan itibaren ise kurum içi iletişim ağlarının (intranet) kullanılmaya başlanmasıyla, çalışanlar da aktif olarak iç iletişim sürecine dâhil olmaya başlamıştır. Günümüzde, kurum içi iletişimi sürdürmek için kurumlarda ayrı iç iletişim birimleri bulunmaktadır (Alparslan, 2018). 
Kavramsal olarak incelendiğinde kurum içi iletişim; kurumun çalışanları veya birimleri arasındaki bilgi iletimidir. Bir organizasyonun tüm seviyelerinde ve birimlerinde gerçekleşir.

Diğer bir tanıma göre de kurum içi iletişim; kurumun amaç ve hedeflerini çalışanlarına bildirmesi ve bu amaç ve hedefler doğrultusunda çalışanlarının davranışlarını yönlendirilmesidir. Aynı zamanda kurum içi iletişim ile kurumda birimler arası koordinasyon sağlanmaktadır (Tutar, 2009, s. 159).

Kurumlar iç iletişimi sağlayamadıklarında amaç ve hedeflerine ulaşmakta güçlük çekmektedirler. Herhangi bir kurumda iç iletişimin etkin bir şekilde var olması, çalışanlar ve birimler arası koordinasyonu kolaylaştırmakta, bunun sonucunda da amaç ve hedeflere ulaşılabilmektedir.

\subsubsection{Kurum İçi İletişimin Amaçlan}

Kurum içi iletişimin en temel amacı, kurumun temel amaç ve hedeflerinin çalışanlar ile paylaşılmasını sağlamak ve bu yolla amaç ve hedeflere ulaşılmasını sağlamaktır. Bunun yanında, kurum içi iletişim ile kurumun stratejileri çalışanlara duyurulmakta, çalışma düzeni, kariyer olanakları ve yan haklar gibi konular hakkında da çalışanlara bilgi verilmesi mümkün olmaktadır (Tutar ve Yılmaz, 2012, s.193).

Kurumların amaç ve hedeflerine ulaşması için en önemli aracı insan kaynağıdır. İnsan kaynağı koordinasyonunun sağlaması için de en önemli araç kurum içi iletişimdir. Etkin bir iç iletişim ağının olabilmesi, kurumlarda üst kademe yöneticilerin doğru ve etkin bir iç iletişim stratejisi belirlemesiyle mümkün olmaktadır. Bu nedenle, yöneticiler tarafından iç iletişimde nasıl bir yol izleneceği ve hangi araçların kullanılacağının belirlenmesi gerekmektedir. Diğer yandan, etkin bir iç iletişimin olduğu kurumlarda çalışanların performansı daha yüksek olmaktadır. Çünkü iletişim sayesinde çalışanlar kurumları hakkında olumlu ya da olumsuz fikirlere sahip olmaktadır. İç iletişimin doğru politikalarla yürütüldügüu kurumlarda çalışanlar kurumun amaç ve hedefleri doğrultusunda çalışmak için gönüllü olmakta ve daha yüksek performansla çalışmaktadır (Demirel, Seçkin ve Özçınar, 2011, s.34).

\subsubsection{Kurum İçi İletişimin İşlevleri}

Kurum içi iletişimin işlevleri genel olarak bilgi sağlama, ikna etme ve etkileme, emredici ve öğretici iletişim kurma ile birleştirme başlıkları altında incelenmektedir.

\subsubsection{Bilgi Sağlama}

İletişim kavramsal olarak ele alındığında en temel işlevi bilgi sağlamaktır. Kurum içi iletişimin olmadığı bir organizasyonda, kurumun hedef ve amaçlarının çalışanlara iletilmesi mümkün olamamaktadır. Ayrıca, yapılacak bir işin nasıl yapılacağı, kimlerin yapacağı gibi faaliyetlerin devamlılığını sağlayacak durumlar da kurum içi iletişim kanalıyla olmaktadır. Bu nedenle, bilgi sağlama kurum içi iletişimin birincil işlevidir.

Kurum içi iletişimin bilgi sağlama işlevi çalışan, yönetici ve kurum dışı ilgililer olmak üzere üç gruba bilgi alışverişi sağlamaktadır. Yönetimin etkin olması ve kurumun etkin çalışması için çok ve çeşitli bilginin olması gerekmektedir. Söz konusu bilginin düzenlenmesi ve zamanlaması kurumun başarısında önemli bir rol oynamaktadır (Güllüoğlu, 2012, s. 26).

\section{Tablo 2.1. Kurumun Farklı Çalışanları Açısından Bilgi İhtiyaçları}

\section{1. Üst Düzey Yönetici İhtiyaçları}

- Çalışanların kuruma karşı tutumlarını bilme

- Kurumun kural, program ve politikalarının ne kadar iyi anlaşıldığını bilme

- Çalışanların verimliliğine katkıda bulunma yolların tahmin edebilme

- Çalışanların şikâyetleri ve söylentileri

\section{Orta Düzey Yönetici İhtiyaçları}

- Denetleme yetkileri

- Denetleme otoritesinin sinırları

- Sendikal ilişkiler ve ilgili politikalar

- Üst yönetim ve bölümlerle ilişkiler 
3. Çalışanların İhtiyaçları

İş Hakkında Bilgi

- Gelişme ve ilerleme imkânları

- İş güvenliği

- Eğitim firsatları

- Ücretlendirme politikası

- Hizmet programı

- Menfaat

- Birim performans1

- Gelecekteki istihdam durumu

\section{Kurum Hakkında Bilgi}

- Kurumun tarihi

- Piyasadaki algisi

- Finansal durumu

- Araştırma faaliyetleri

- Ürünler ve reklam programı

- Sendika ilişkileri

- Yönetim ve kurum politikaları

- Büyüme planları

\subsubsection{2. İkna Etme ve Etkileme}

İki ayrı kavram olarak kullanılan ikna etmek ve etkilemek kurum içi iletişimin bir diğer işlevlerindendir. Sözlük anlamı olarak bakıldığında etkilemek; "karşısındaki kişiyi kendi duygu ve istekleri doğrultusuna yöneltmek" anlamında kullanılmaktadır (TDK). Kavramsal olarak uzun vadeli bir sürece işaret etmektedir. İkna etmek de benzer bir şekilde kişilerin tutum ve davranışlarını istenilen yönde değişmesini sağlamaktır.

Kurumların yönetiminde güç ve otorite ile çalışanların istenileni yapmasını sağlamaya çalışmak kalıcı ve uzun vadeli olmamaktadır. Bu noktada, kurum içi iletişimin ikna etme ve etkileme işlevlerinden yararlanılarak, çalışanların yapılması istenilen şeyleri benimsemesi ve gönüllü olarak yapması sağlanmaktadır. Çünkü güç ve otorite ile iş yaptırmaya çalışılan kurumlarda çalışanların kurumsal bağlllıkları düşük olmaktadır (Güllüoğlu, 2012, s. 26).

\subsubsection{Emredici ve Öğretici İletişim Kurma}

Üst kademe yöneticilerin alt kademe çalışanları ile kurdukları iletişim sadece bilgi paylaşma kapsamında değerlendirilmemelidir. İç iletişim aracılığıyla, alt kademe çalışanların tutum ve davranışlarına yön vermek ve hangi işin nasıl yapılacağını öğretmek gibi amaçlar da yer almaktadır. Kurum hedeflerin yerine getirilmesinde çalışanların performans gösterebilmeleri için gerek duydukları eğitim ihtiyaçlarının giderilmesi gerekmektedir (Bahar, 2011, s.10).

\subsubsection{Birleştirme ve Eşgüdüm Sağlama}

Kurum içi iletişimin en önemli işlevi olan eşgüdüm sağlama işlevi, diğer üç işlevinin koordinasyonlu bir şekilde çalışmasını sağlamaktır. Bu işlevler eşgüdümlü olarak çalışmazsa, kurum içi iletişimin etkinliği ve başarısı azalmaktadır (Güllüoğlu, 2012, s. 26). Birleştirme işlevi ise kurum içi iletişimin kurumun hedef ve amaçları etrafında çalışanları toplamasını ifade etmektedir.

\subsubsection{Kurum İçi İletişimin Etkinliğini Etkileyen Faktörler}

İç iletişim genellikle kuruluşun can damarı olarak adlandırılır. Kurumlardaki iç sorunların büyük çoğunluğu doğrudan etkisiz iç iletişim ile ilgilidir. Kötü iç iletişim, kuruluşun diğer alanlarını etkiler ve çalışanlar arasında kötü duygulara ve zayıf ilişkilere neden olabilir. Yetersiz veya uygunsuz iletişim öfkeye ve güvensizliğe yol açar. Bu nedenle, iç iletişimin etkinliğini azaltan ana faktörleri tespit etmek, bunların kontrolden çıkmalarını engellemek için gereklidir. Kurum içi iletişimin etkinliğini etkileyen faktörler aşağıda yer almaktadır (Chmielecki, 2015, s.28-30):

\section{Mikro Düzeyde Etkileyen Faktörler:}

- Çalışan iletişim yetkinliği: Herhangi bir insan iletişim sisteminin en belirgin ve önemli yönüdür. Bu nedenle, eğer iletişim yetkinliği geliştirilirse, kişilerarası iletişimin etkinliğini ve dolayısıyla kurumların büyük organizasyonel süreçlerinin verimliliği arttırılır. Diğer yandan, iletişim yeterliliğinin gelişmesi bazı koşullara bağlıdır. İletişim kurmak için bilgi, beceri ve motivasyon gerekir. İletişim yeterliliği bir kurumda özellikle, bir çalışanın yeterli sunum, müzakere, retorik, dilbilimsel ve bilgi organizasyonu becerilerine dayanır.

- Bir kurumun iletişim stratejisi ve değerleri ile belirlenen tüm kurum çalışanlarının kişisel iletişim tarzı, iletişim yeterlilik parametrelerinin geliştirilmesinden kaynaklanır ve iletişim uygulamalarının etkinliğine hizmet eder. 
- İlgili mesaj veya bilgi algısı ve yeterli bilgi sınıflandırması ile geri bildirim, iletişimciler arasında etkili etkileşime izin verir.

- Sözlü mesajların dikkatli bir şekilde yapılandırılması ve organize edilmesi, herhangi bir iletişim kanalı ve organizasyon iletişimi ile sistemi için uygun bir formatın yerleştirilmesine izin verir.

- Bir kurumun tüm hiyerarşik düzeylerinden iletişimcilerin katılımıyla biçimsel ya da biçimsel olmayan iletişim ağlarının etkili bir şekilde seçilmesi genellikle sadece iletişimin değil diğer organizasyonel süreçlerin de başarısını belirler.

- Sözlü ve sözel olmayan bir iletişim türünün veya her ikisinin de etkili ve bilinçli kullanımı, özellikle karmaşı ortamlarda kişilerarası iletişim başarısını belirler.

- Bireysel iletişimciler tarafından kullanılan ilgili kurum içi iletişim araçları, tüm kurum içi iletişim aşamalarında ve daha geniş uygulamalarda çok önemli bir faktördür.

- Kişisel iletişim engellerini, örneğin farklı değerleri, algılama özelliklerini, tutumlarını, vb. veya anlamsal, fiziksel, sosyo-kültürel engelleri belirlemek ve aşmak, herhangi bir kurum ortamında etkili iletişimin doğrudan bir göstergesidir.

\section{Orta Düzeyde Etkileyen Faktörler:}

- İletişim sisteminin ve tüm alt sistemlerinin, organizasyonun hedefleri ile entegrasyonu önemlidir. Çünkü yöneticiler koordine eden ve kontrol eden kişilerdir.

- Liderlik ve yönetim tarzı (bilginin etkin dağıtımı ve kullanımı, iletişim kurma isteği, geri bildirimle etkili dikey iletişim ve çalışanların kendi farkındalığını teşvik etme), özellikle teknolojiye dayalı iletişimin aksine gerçek zamanlı iletişimleri besleyen doğrudan iletişimi teşvik eder veya engeller.

- Alakalı bir iletişim kanalının başarılı bir şekilde seçilmesi (yazılı ve sözlü veya teknoloji aracılı), kurum yönetimi arasındaki hiyerarşik iletişimin tüm düzeylerinde birincil öneme sahiptir; doğrudan kurum hedeflerine ulaşılmasını kolaylaştırır.

- Etkili çatışma yönetimi, yani tüm iletişim süreci katılımcıları için yönetimin ayrıcalığı olarak açık bilgi alışverişi, hoşgörü ve empati.

- Bir organizasyonda verimli yatay iletişim akışlarına olanak sağlayan ilgili bilgi temini, etkili dinleme, bilgili bilgi analizi, verimli sorgulama ve sinerji gibi etkili grup iletişimi [becerileri].

\section{Makro Düzeyde Etkileyen Faktörler:}

- Kurumsal hedefler, yani iletişim ve iletişimcilere değer veren misyon beyanları ile genel bir iletişim stratejisi, bir organizasyondaki iletişimin temelini oluşturur. Örneğin, sistemin açıklığı, geri bildirim sağlama ve alma, iş birliği, biçimsel olmayan iletişimlere değer verme, değişime açıklık, risk toleransı, öğrenme ve iyileştirme gibi organizasyonel iletişim değerleri esas olarak kurumun omurgasını destekler.

- Bir kurumun dış ve iç iletişimi arasında bir uyum olarak kendini gösteren güçlü iletişim etiği, tüm çıkar gruplarıyla olumlu ilişkiler, çalışanlar için etik bilgi ve yönetim de bir iletişim sistemi arka planı oluşturur.

- Organizasyonel iletişim engellerini (motivasyon eksikliği, aşırı bilgi yüklemesi, rekabet, yetersiz yönetim tarzı) belirlemek ve üstesinden gelmek, bazen bir organizasyondaki stratejik bükülmelere meydan okuyan büyük iletişim sorunlarını çözebilir.

- İletişim sistemindeki tüm parametrelerin, özellikle dikey iletişim hatları boyunca, tüm parametrelerin etkililiğini ve dinamiklerini güvence altına alırken, iletişim süreçlerinde uygun geri bildirim çok önemlidir. Etkili iletişimin en etkili faktörlerinden biri olarak, bir organizasyonda bütünsel işleyen bir iletişim sisteminin itici gücü olarak hizmet eder.

- Organizasyon yapısının, bilgi akışını sağlamak, iletişimcilerin mesajlar arasında dolaşımını sağlamak ve tüm etkileşim seviyeleri hakkında hızı geri bildirim sağlamak için gözden geçirilmesi gerekmektedir.

- Etkileşimde sinerjiye izin veren bir iletişim sistemi oluşturma kararlılı̆̆ı, etkili iletişim arayışında temel faktörlerden biridir.

\section{Yöntem}

Kurumsal bağlılığa ilişkin yapılan sınıflandırmalardan en çok kullanılanı Allen ve Meyer'in sınıflandırmasıdır. Bu sınıflandırmaya göre kurumsal bağlılık, duygusal, devam ve normatif bağlllıktan oluşmaktadır. Allen ve Meyer (1990-1993) bu bağlılıkları analiz etmek için bir ölçek oluşturmuşlardır. 
F. Bulut - M. Tolon 13/2 (2021) 1255-1272

Araştırmada kurum içi iletişim ile kurumsal bağlılık boyutlarının aralarındaki ilişkinin ne yönde ve düzeyde olduğu ile demografik özelliklerin, kurumsal bağlllık boyutlarını etkileyip etkilemediği tespit edilmeye çalışılmıştır.

\subsection{Araştırmanın Modeli}

Araştırmada ilk kısım sorularını oluşturan demografik özelliklerin kurumda dağılımına ilişkin yüzde dağılımı çıkarılmış ve kurumsal bağlılık boyutları ile ilişkileri incelenmiştir.

Anketin daha sonraki kısımlarında yer alan ifadelerin frekans, yüzde ve ortalama değeri bulunarak çalışanların kurum içi iletişime ve kurumsal bağlılığa ilikin görüşleri analiz edilmiştir.

Ayrıca, kurum içi iletişim unsurlarının kurumsal bağlılık boyutlarındaki etkilerini tespit etmek için aşağıda Tablo 3.1.'de yer alan hipotezler geliştirilmiştir:

\section{Tablo 3.1. Araştırmanın Hipotezleri}

\begin{tabular}{|c|c|}
\hline $\begin{array}{l}\text { H01. İç iletişimin, duygusal bağlllık üzerinde } \\
\text { anlamlı bir etkisi yoktur. }\end{array}$ & $\begin{array}{l}\text { H1. İç iletişimin, duygusal bağlılık üzerinde anlamlı } \\
\text { bir etkisi vardır. }\end{array}$ \\
\hline $\begin{array}{l}\mathrm{HO}_{2} \text {. İç iletişimin, devamlıllık bağ llı̆ı̆ı üzerinde } \\
\text { anlamlı bir etkisi yoktur. }\end{array}$ & $\begin{array}{l}\text { H12. İç iletişimin, devamlılık bağ } \operatorname{ll}_{1} \operatorname{lğg}_{1} \text { üzerinde anlamlı } \\
\text { bir etkisi vardır. }\end{array}$ \\
\hline $\begin{array}{l}\mathrm{H}_{3} \text {. İç iletişimin, normatif bağlılık üzerinde } \\
\text { anlamlı bir etkisi yoktur. }\end{array}$ & $\begin{array}{l}\text { H13. İç iletişimin, normatif bağlllık üzerinde anlamlı bir } \\
\text { etkisi vardır. }\end{array}$ \\
\hline $\begin{array}{l}\text { H04. Yönetim yaklaşımının, duygusal bağlılık } \\
\text { üzerinde anlamlı bir etkisi yoktur. }\end{array}$ & $\begin{array}{l}\text { H14. Yönetim yaklaşımının, duygusal bağlılık üzerinde } \\
\text { anlamlı bir etkisi vardır. }\end{array}$ \\
\hline $\begin{array}{l}\text { H05. Yönetim yaklaşımının, devamlılık bağlılığ } \\
\text { üzerinde anlamlı bir etkisi yoktur. }\end{array}$ & $\begin{array}{l}\text { H15. Yönetim yaklaşımının, devamlılık bağlılığı } \\
\text { üzerinde anlamlı bir etkisi vardır. }\end{array}$ \\
\hline $\begin{array}{l}\text { H06. Yönetim yaklaşımının, normatif bağlllık } \\
\text { üzerinde anlamlı bir etkisi yoktur. }\end{array}$ & $\begin{array}{l}\text { H16. Yönetim yaklaşımının, normatif bağlllık üzerinde } \\
\text { anlamlı bir etkisi vardır. }\end{array}$ \\
\hline $\begin{array}{l}\text { H07. Bilgi paylaşımın, duygusal bağlılık üzerinde } \\
\text { anlamlı bir etkisi yoktur. }\end{array}$ & $\begin{array}{l}\text { H17. Bilgi paylaşımın, duygusal bağlılık üzerinde } \\
\text { anlamlı bir etkisi vardır. }\end{array}$ \\
\hline $\begin{array}{l}\text { H08. Bilgi paylaşımının, devam bağlılığı üzerinde } \\
\text { anlamlı bir etkisi yoktur. }\end{array}$ & $\begin{array}{l}\text { H1s. Bilgi paylaşımının, devam bağlılığı üzerinde } \\
\text { anlamlı bir etkisi vardır. }\end{array}$ \\
\hline $\begin{array}{l}\text { H09. Bilgi paylaşımının, normatif bağlllık } \\
\text { üzerinde anlamlı bir etkisi yoktur. }\end{array}$ & $\begin{array}{l}\text { H19. Bilgi paylaşımının, normatif bağlllık üzerinde } \\
\text { anlamlı bir etkisi vardır. }\end{array}$ \\
\hline $\begin{array}{l}\text { H010. Biçimsel olmayan iletişimin, duygusal } \\
\text { bağll1ık üzerinde anlamlı bir etkisi yoktur. }\end{array}$ & $\begin{array}{l}\text { H110. Biçimsel olmayan iletişimin, duygusal bağlılık } \\
\text { üzerinde anlamlı bir etkisi vardır. }\end{array}$ \\
\hline $\begin{array}{l}\text { H011. Biçimsel olmayan iletişimin, devam bağlılığı } \\
\text { üzerinde anlamlı bir etkisi yoktur. }\end{array}$ & 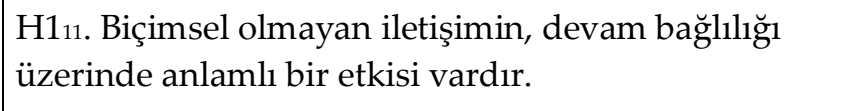 \\
\hline $\begin{array}{l}\text { H012. Biçimsel olmayan iletişimin, normatif } \\
\text { bağlılık üzerinde anlamlı bir etkisi yoktur. }\end{array}$ & $\begin{array}{l}\text { H112. Biçimsel olmayan iletişimin, normatif bağlılık } \\
\text { üzerinde anlamlı bir etkisi vardır. }\end{array}$ \\
\hline
\end{tabular}

\subsection{Evren ve Örneklem}

Araştırmanın evrenini, 3743 kurum çalışanı oluşturmaktadır. Çeşitli unvan grupları araştırmanın kapsamı dışında kaldığı için dâhil edilmemiştir. Yapısı homojen olmayan bu örneklem için \%95 güven aralığında \pm \%5 
örnekleme hatası ile hesaplama yapılmış ve örneklem büyüklügünün en az n = 349 kişi olması gerektiği tespit edilmiştir

Elektronik olarak online bir sistem üzerinden uygulanan anket için evrenden örneklem seçilmemiş, kişilere eposta ile anketin linki gönderilerek gönüllü katılımla evrenin kendini örneklemesi hedeflenmiştir. Sonuçta 652 kişi anketi tam olarak doldurmuş, araştırma sonuçlarının \%95 güven aralığında ve $\pm \% 5$ örnekleme hatası ile genelleyebileceği yeterli örneklem hacmine ulaşılmıştır

\subsection{Veri Toplama Araçları}

Araştırmada ölçüm aracı olarak anket kullanılmıştır. Ankette 3 bölüm bulunmaktadır. İlk bölüm demografik sorulardan, ikinci bölüm kurumsal bağlılığı ölçmeye yönelik sorulardan, üçüncü bölüm ise kurum içi iletişimi ölçmeye yönelik sorulardan oluşmaktadır.

Anketin birinci kısmında katılımcıların demografik özelliklerinin belirlenmesi amacıyla, çalıştıkları birim, cinsiyet, medeni durum, yaş, öğrenim durumu, bu kurum öncesinde başka bir işte çalışıp çalışmama, bu kurumdaki toplam hizmet süresi ve sahip olunan unvandaki hizmet süresine ilişkin toplam 8 soru sorulmuştur.

Katılımcılara, anketin ikinci kısmında, kurumsal bağlılık ile ilgili 18 soru sorulmuştur. Anketin bu kısmında Tamer Gündoğan'ın 2009 yılında yapmış olduğu uzmanlık tezinden izin alınarak yararlanılmıştır. Ölçek olarak geçerliliği ve güvenilirliği Gündoğan tarafından yapılan ve Türkçe'ye çevrilen "Üç Boyutlu Örgütsel Bağlılık Ölçeği" (Allen ve Meyer, 1990) kullanılmıştır. Katılımcılara, anketin son kısmında, kurum içi iletişime ilişkin 21 soru sorulmuştur. Ölçek olarak Emine Yılmaz'ın 2011 yılında yapmış olduğu yüksek lisans tezinden, danışmanı Prof.Dr. Adem Uğur'dan izin alınarak yararlanılmıştır.

Her iki bölümün tamamında beş basamaklı Likert tipi ölçek kullanılmıştır. Bu kapsamda, benimsenen beşli ölçekteki seçenekler; "Kesinlikle katılmıyorum", "Katılmıyorum", "Kararsızım", "Katıllyorum" ve "Tamamen katılıyorum" şeklinde oluşturulmuştur.

Anket formunda kurumsal bağlılık ve kurum içi iletişim anketleri için 5’li Likert Ölçeği kullanılmıştır. Buna göre; I - Kesinlikle katılmıyorum, II - Katılmıyorum, III - Kararsızım, IV - Katılıyorum,

V - Kesinlikle katılıyorum şeklinde puanlandırılmıştır.

\subsection{Verilerin Analizi}

Verilerin analizinde SPSS 20.0 istatistik programı kullanılmıştır.

\section{Analiz ve Bulgular}

\subsection{Demografik Özelliklere İlişkin Sonuçlar}

Kurumsal bağlılık ile ilgili literatür incelendiğinde yaş ve çalışma sürelerinin bağlllık üzerinde etkisi olduğu vurgulanmıştır. Bu nedenle analizlerde bu değişkenler kullanılmıştır. Diğer yandan, bir görüş birliği bulunmamakla birlikte cinsiyet değişkeninin de etkisi olduğundan bahsedilmektedir. Kurumumuzda cinsiyet değişkeninin bağllık üzerinde bir etkisinin olup olmadığının incelenmesi amacıyla bu değişken de analizlere eklenmiştir.

Tablo 3.2. Cinsiyete Göre Kurumsal Bağllılı ve Kurum İçi İletişim Karşılaştırmasına Yönelik T-Testi Analizi

\begin{tabular}{|l|l|c|c|c|c|c|c|}
\hline & Cinsiyetiniz & $\mathrm{N}$ & Ortalama & $\mathrm{S}$ & $\mathrm{t}$ & $\mathrm{Sd}$ & $\mathrm{p}$ \\
\hline \multirow{2}{*}{ Kurumsal Bağllık } & Erkek & 473 & 64,7526 & 8,01139 & 1,526 & 625 & 0,128 \\
\cline { 2 - 7 } & Kadın & 154 & 63,6299 & 7,68068 & & & \\
\hline \multirow{2}{*}{ Kurum İçi İletişim } & Erkek & 473 & 55,3827 & 7,29751 & 0,729 & 625 & 0,466 \\
\cline { 2 - 7 } & Kadın & 154 & 54,8961 & 6,84771 & & & \\
\hline
\end{tabular}

Cinsiyete göre kurumsal bağlılık düzeyinin ve kurum içi iletişim düzeyinin karşılaştırılması için yapılan ttesti analiz sonuçları Tablo 3.2' de gösterilmektedir. Buna görehem kurumsal bağlllık açısından hem de iç iletişim açısından kadın ve erkek çalışanların istatistiksel olarak anlamlı bir farklılık $(p>0,05)$ göstermediği sonucuna varılmıştır. 
F. Bulut - M. Tolon 13/2 (2021) 1255-1272

Tablo 3.3. Farklı Yaş Gruplarına Göre Kurumsal Bağlılık ve Kurum İçi İletişim Karşılaştırmasına Yönelik Anova Analizi

\begin{tabular}{|c|c|c|c|c|c|c|}
\hline & & $\mathrm{N}$ & Ortalama & s.s. & $\mathrm{F}$ & $\mathrm{p}$ \\
\hline \multirow{8}{*}{ Kurumsal Bağlılık } & $18-30$ & 79 & 62,519 & 8,2086 & \multirow{8}{*}{5,241} & \multirow{8}{*}{0,000} \\
\hline & $31-35$ & 144 & 63,8819 & 8,77416 & & \\
\hline & $36-40$ & 170 & 63,6118 & 7,62368 & & \\
\hline & $41-45$ & 116 & 64,5431 & 7,59335 & & \\
\hline & $46-50$ & 66 & 66,803 & 6,88637 & & \\
\hline & $51-55$ & 34 & 67,9118 & 6,43554 & & \\
\hline & 56 ve üzeri & 18 & 70,5556 & 4,81691 & & \\
\hline & Total & 627 & 64,4769 & 7,94011 & & \\
\hline \multirow{8}{*}{ Kurum İçi İletişim } & $18-30$ & 79 & 54,3924 & 6,95852 & \multirow{8}{*}{3,205} & \multirow{8}{*}{0,004} \\
\hline & $31-35$ & 144 & 55,4514 & 8,53035 & & \\
\hline & $36-40$ & 170 & 54,1647 & 7,02379 & & \\
\hline & $41-45$ & 116 & 55,1983 & 5,96398 & & \\
\hline & $46-50$ & 66 & 56,4091 & 6,73447 & & \\
\hline & $51-55$ & 34 & 57,2353 & 6,49969 & & \\
\hline & 56 ve üzeri & 18 & 60,4444 & 4,92559 & & \\
\hline & Total & 627 & 55,2632 & 7,18731 & & \\
\hline
\end{tabular}

Farklı yaş gruplarından çalışanların kurumsal bağlılık ve kurum içi iletişim düzeyleri arasındaki farkı belirlemek için yapılan varyans analizi sonucunda farklı yaş gruplarından çalışanların hem kurumsal bağlılık hem de kurum içi iletişim düzeyleri arasında anlamlı bir farklılık $(p<0,05)$ bulunmuştur. Çalışanların yaşları yükseldikçe kurumsal bağlılıklarının arttığı görülmektedir.

Tablo 3.4. Çalışma Süresine Göre Kurumsal Bağlılık ve Kurum İçi İletişim Karşılaştırmasına Yönelik Anova Analizi

\begin{tabular}{|c|c|c|c|c|c|c|}
\hline & & $\mathrm{N}$ & Ortalama & s.s. & $\mathrm{F}$ & $\mathrm{p}$ \\
\hline \multirow{6}{*}{ Kurumsal Bağlılık } & 4 yildan az & 35 & 63,0286 & 8,19069 & \multirow{6}{*}{6,331} & \multirow{6}{*}{0,000} \\
\hline & $1-5$ yil & 87 & 63,1264 & 9,65185 & & \\
\hline & 6-10 yıl & 109 & 64,0642 & 7,55998 & & \\
\hline & 11-20 y1l & 273 & 63,8571 & 7,51308 & & \\
\hline & 21 yıl ve üzeri & 123 & 67,5854 & 7,0733 & & \\
\hline & Total & 627 & 64,4769 & 7,94011 & & \\
\hline \multirow{6}{*}{ Kurum İçi İletişim } & 4 yıldan az & 35 & 53,9714 & 5,89858 & \multirow{6}{*}{2,485} & \multirow{6}{*}{0,043} \\
\hline & $1-5$ yil & 87 & 54,8391 & 9,48545 & & \\
\hline & 6-10 yıl & 109 & 55,633 & 7,1371 & & \\
\hline & $11-20$ yil & 273 & 54,6813 & 6,64246 & & \\
\hline & 21 yıl ve üzeri & 123 & 56,8943 & 6,65646 & & \\
\hline & Total & 627 & 55,2632 & 7,18731 & & \\
\hline
\end{tabular}

Farklı çalışma süresine sahip çalışanların kurumsal bağlılık ve kurum içi iletişim düzeyleri arasındaki farkı belirlemek için yapılan varyans analizi sonucunda farklı çalışma süresine sahip çalışanların hem kurumsal bağlılık hem de kurum içi iletişim düzeyleri arasında anlamlı bir farklılık $(p<0,05)$ olduğu tespit edilmiştir. Yaş değişkenindekine paralel olarak, Kurum'da çalışma süresi arttıkça çalışanların kurumsal bağlılıklarının arttığı görülmüştür. 
F. Bulut - M. Tolon 13/2 (2021) 1255-1272

\subsection{Kurum İçi İletişim ve Kurumsal Bağlılık Boyutlarına İlişkin Analizler}

Tablo 3.5. Kurum İçi İletişim Boyutlarının Ortalama ve Standart Sapmaları

\begin{tabular}{|l|c|c|c|c|c|c|}
\hline & $\mathrm{N}$ & Minimum & Maximum & Toplam & Ortalama & s.s. \\
\hline İç İletişim & 627 & 6 & 30 & 13672 & 21,8054 & 4,06895 \\
\hline Yönetim yaklaşımı & 627 & 5 & 25 & 9647 & 15,386 & 4,97608 \\
\hline Bilgi Paylaşımı & 627 & 5 & 25 & 10178 & 16,2329 & 4,26292 \\
\hline Biçimsel Olmayan İletişim & 627 & 5 & 25 & 10434 & 16,6411 & 2,76452 \\
\hline Toplam & 627 & 32 & 78 & 34650 & 55,2632 & 7,18731 \\
\hline
\end{tabular}

Kurum içi iletişim boyutlarının ortalamalarına ve standart sapmalarına ilişkin yapılan analiz incelendiğinde ortalama değeri en yüksek olan iç iletişim unsuru iken, en düşük olanın yönetim yaklaşımı unsuru olduğu görülmektedir.

Tablo 3.6. Kurumsal Bağllık Boyutlarının Ortalama ve Standart Sapmaları

\begin{tabular}{|l|c|c|c|c|c|c|}
\hline & N & Minimum & Maximum & Toplam & Ortalama & s.s. \\
\hline Duygusal Bağlılık & 627 & 6 & 30 & 13448 & 21,4482 & 4,80931 \\
\hline Devam Bağlılığı & 627 & 8 & 27 & 9967 & 15,8963 & 2,54049 \\
\hline Normatif Bağlılık & 627 & 4 & 20 & 7696 & 12,2743 & 2,20253 \\
\hline Toplam & 627 & 38 & 84 & 40427 & 64,4769 & 7,94011 \\
\hline
\end{tabular}

Kurumsal bağlılık boyutlarının ortalamalarına ve standart sapmalarına ilişkin yapılan analiz incelendiğinde ise ortalama değeri en yüksek olan bağlılık türü duygusal bağlllıkiken, en düşük olanın normatif bağlllık olduğu görülmektedir.

Tablo 3.7. Kurum İçi İletişim ve Kurumsal Bağlllık Boyutlarının Korelasyon Değerleri

\begin{tabular}{|c|c|c|c|c|}
\hline & & $\begin{array}{c}\text { Duygusal } \\
\text { Bağlilık }\end{array}$ & Devam Bağl1lığ1 & Normatif Bağllilık \\
\hline \multirow{2}{*}{ İç İletişim } & Pearson Korelasyonu &, $580^{* * *}$ &,$- 329^{* *}$ & $367^{* * *}$ \\
\hline & p (2-yönlü) & 0 & 0 & 0 \\
\hline \multirow{2}{*}{ Yönetim Yaklaşımı } & Pearson Korelasyonu &, $535^{* *}$ &,$- 257^{* * *}$ & ,332** \\
\hline & $\mathrm{p}$ (2-yönlü) & 0 & 0 & 0 \\
\hline \multirow{2}{*}{ Bilgi Paylaşımı } & Pearson Korelasyonu &, $554^{* *}$ &,$- 269^{* *}$ & ,359** \\
\hline & p (2-yönlü) & 0 & 0 & 0 \\
\hline \multirow{2}{*}{$\begin{array}{l}\text { Biçimsel Olmayan } \\
\text { İletişim }\end{array}$} & Pearson Korelasyonu & $426^{* *}$ &,$- 193^{* *}$ & $282^{* * *}$ \\
\hline & p (2-yönlü) & 0 & 0 & 0 \\
\hline
\end{tabular}

**. Correlation is significant at the 0.01 level (2-tailed).

Kurum içi iletişim değişkenleri ile kurumsal bağlllık boyutlarının arasındaki korelasyon değerleri incelendiğinde;

Duygusal bağlılık ile; iç iletişim, önetim yaklaşımı, kurum içi bilgi paylaşımı ve biçimsel olmayan iletişim arasında orta derece pozitif yönlü bir ilişki bulunmaktadır.

Devamlılık bağlılı̆̆ ile; iç iletişim arasında orta derece negatif yönlü bir ilişki bulunurken, yönetim yaklaşımı ile arasında zayıf negatif yönlü bir ilişki bulunmaktadır. 
Normatif bağlılık ile; iç iletişim, yönetim yaklaşımı ve kurum içi bilgi paylaşımı arasında orta derece pozitif yönlü bir ilişki bulunurken, biçimsel olmayan iletişim ile arasında zayıf pozitif yönlü bir ilişki bulunmaktadır.

\subsubsection{Kurum İçi İletişim Unsurlarının Kurumsal Bağlılık Boyutlarıyla İlişkisi}

Kurum içi iletişimin boyutları olan iç iletişim, yönetim yaklaşımı, biçimsel olmayan iletişim ve bilgi paylaşımının kurumsal bağlılık boyutları ile ilişkisini belirlemek için çoklu regresyon analizi uygulanmıştır.

Tablo 3.8. Kurum İçi İletişim Unsurlarının Duygusal Bağlllıkla İlişkilerine Yönelik Çoklu Regresyon Analizi

\begin{tabular}{|c|c|c|c|}
\hline Model Özeti & & & \\
\hline $\mathrm{R}$ & $\mathrm{R}^{2}$ & Düzeltillmiş $\mathrm{R}^{2}$ & Tahminin Standart Hatası \\
\hline, $612^{\mathrm{a}}$ & 0,374 & 0,37 & 3,8164 \\
\hline
\end{tabular}

a. Tahmin ediciler (yordayıcı): (Constant), Biçimsel Olmayan İletişim, Bilgi Paylaşımı, Yönetim Yaklaşımı, İç İletişim

\begin{tabular}{|c|c|c|c|c|c|c|c|c|c|c|c|c|c|}
\hline \multicolumn{14}{|c|}{ Katsayılara } \\
\hline \multirow{2}{*}{\multicolumn{2}{|c|}{ Model }} & \multicolumn{2}{|c|}{$\begin{array}{l}\text { Standartlanmamış } \\
\text { Katsayilar }\end{array}$} & \multirow{2}{*}{\begin{tabular}{|c}
$\begin{array}{c}\text { Standartlaştırılmış } \\
\text { Katsayılar }\end{array}$ \\
Beta
\end{tabular}} & \multirow{2}{*}{$\mathrm{t}$} & \multirow{2}{*}{$\mathrm{p}$} & \multicolumn{2}{|c|}{$\begin{array}{c}\text { B için \%95 } \\
\text { Güven } \\
\text { Aralığ1 }\end{array}$} & \multicolumn{3}{|c|}{ Korelasyonlar } & \multirow{2}{*}{$\begin{array}{c}\begin{array}{c}\text { Eşdoğrusallık } \\
\text { İstatistikleri }\end{array} \\
\text { Tolerance }\end{array}$} & \multirow[b]{2}{*}{ VIF } \\
\hline & & B & $\begin{array}{c}\text { Standart } \\
\text { Hata }\end{array}$ & & & & $\begin{array}{c}\text { Alt } \\
\text { Sinir }\end{array}$ & $\begin{array}{c}\text { Üst } \\
\text { Sınır }\end{array}$ & $\begin{array}{c}\text { Sifır } \\
\text { derece }\end{array}$ & Kismi & Part & & \\
\hline \multirow{5}{*}{1} & (Sabit) & 6,078 & 1,042 & & 5,831 & 0 & 4,031 & 8,125 & & & & & \\
\hline & İç İletişim & 0,32 & 0,071 & 0,271 & 4,48 & 0 & 0,18 & 0,46 & 0,58 & 0,177 & 0,142 & 0,275 & 3,63 \\
\hline & $\begin{array}{l}\text { Yönetim } \\
\text { Yaklaşımı }\end{array}$ & 0,101 & 0,055 & 0,105 & 1,849 & 0,07 & $\begin{array}{c}- \\
0,006\end{array}$ & 0,209 & 0,535 & 0,074 & 0,059 & 0,314 & 3,185 \\
\hline & $\begin{array}{c}\text { Bilgi } \\
\text { Paylaşımı }\end{array}$ & 0,241 & 0,062 & 0,214 & 3,884 & 0 & 0,119 & 0,363 & 0,554 & 0,154 & 0,123 & 0,333 & 3,006 \\
\hline & $\begin{array}{c}\text { Biçimsel } \\
\text { Olmayan } \\
\text { İletişim }\end{array}$ & 0,176 & 0,07 & 0,101 & 2,52 & 0,01 & 0,039 & 0,313 & 0,426 & 0,101 & 0,08 & 0,625 & 1,6 \\
\hline
\end{tabular}

Duygusal bağlılık ile iletişim boyutları arasındaki ilişki incelendiğinde;

İletişim boyutları değişkenlerine bakıldığında iç iletişim, bilgi paylaşımı ve biçimsel olmayan iletişim unsurlarına ilişkin $\mathrm{p}$ değerlerinin $<0.05$ olduğu görülmektedir. $\mathrm{Bu}$ da bu unsurların, duygusal bağlllık üzerinde anlamlı bir etkisi olduğunu göstermektedir. Bu durumda;

I. "H01. İ̧ iletişimin, duygusal bağlllık üzerinde anlamlı bir etkisi yoktur." hipotezi reddedilmiştir.

II. "H04. Yönetim yaklaşımının, duygusal bağlılık üzerinde anlamlı bir etkisi yoktur." hipotezi reddedilememiştir.

III. "H07. Bilgi paylaşımın, duygusal bağllık üzerinde anlamlı bir etkisi yoktur." hipotezi reddedilmiştir.

IV. "H010. Biçimsel olmayan iletişimin, duygusal bağlılık üzerinde anlamlı bir etkisi yoktur." hipotezi reddedilmiştir. 
F. Bulut - M. Tolon 13/2 (2021) 1255-1272

Tablo 3.9. Kurum İçi İletişim Unsurlarının Devamlılık Bağlılığıyla İlişkilerine Yönelik Çoklu Regresyon Analizi

\begin{tabular}{|c|c|c|c|c|}
\hline \multicolumn{5}{|c|}{ Model Özeti } \\
\hline Model & $\mathrm{R}$ & $\mathrm{R}^{2}$ & Düzeltilmiş $\mathrm{R}^{2}$ & Tahminin Standart Hatası \\
\hline 1 &, $330 \mathrm{a}$ & 0,109 & 0,103 & 2,40608 \\
\hline
\end{tabular}

a. Tahmin ediciler (yordayıcı): (Constant), Biçimsel Olmayan İletişim, Bilgi Paylaşımı, Yönetim Yaklaşımı, İç İletişim

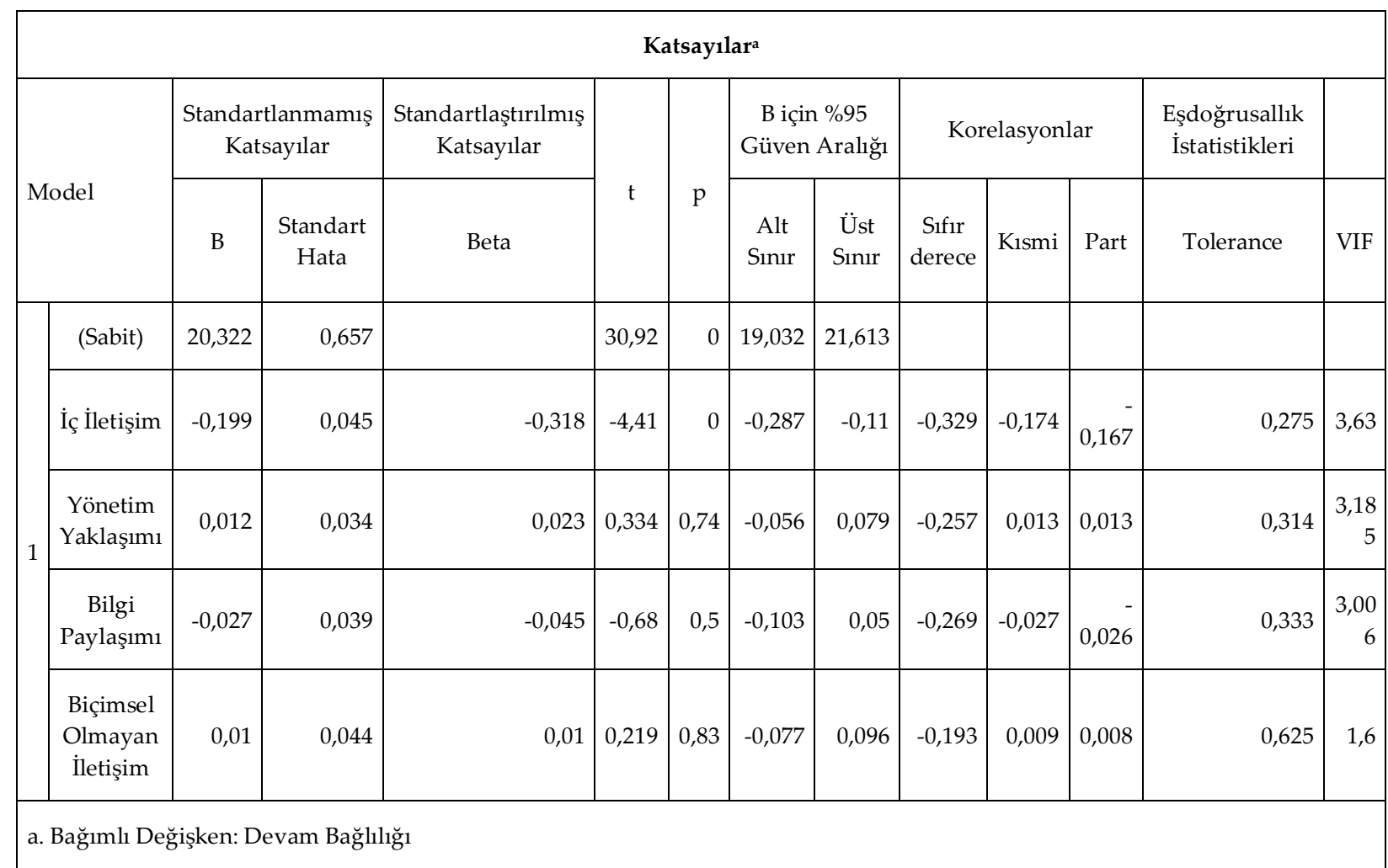

Devam bağlılığı ile iletişim boyutları değişkenleri arasındaki ilişkideğerlendirildiğinde;

İletişim boyutları değişkenlerine bakıldığında yalnızca iç iletişime ilişkin $\mathrm{p}$ değerinin $<0.05$ olduğu görülmektedir. Bu da yalnızca bu unsurun, devamlılık bağlılı̆̆ı üzerinde anlamlı bir etkisi olduğunu göstermektedir. Bu durumda;

- "H02. İç iletişimin, devamlılık bağlılığı üzerinde anlamlı bir etkisi yoktur." hipotezi reddedilmiştir.

- "H05. Yönetim yaklaşımının, devamlılık bağlılı̆̆ı üzerinde anlamlı bir etkisi yoktur." hipotezireddedilememiştir.

- “H08. Bilgi paylaşımının, devam bağllı̆̆g üzerinde anlamlı bir etkisi yoktur” hipotezi reddedilememiştir.

- “H011. Biçimsel olmayan iletişimin, devam bağllığı üzerinde anlamlı bir etkisi yoktur." hipotezi reddedilememiştir. 
F. Bulut - M. Tolon 13/2 (2021) 1255-1272

Tablo 3.10. Kurum İçi İletişim Unsurlarının Normatif Bağll1ık İle İlişkilerine Yönelik Çoklu Regresyon Analizi

\begin{tabular}{|c|c|c|c|c|}
\hline \multicolumn{3}{|c|}{ Model Özeti } \\
\hline Model & $\mathrm{R}$ & $\mathrm{R}^{2}$ & Düzeltilmiş $\mathrm{R}^{2}$ & Tahminin Standart Hatası \\
\hline 1 &, $392^{\mathrm{a}}$ & 0,154 & 0,148 & 2,03281 \\
\hline
\end{tabular}

a. Tahmin ediciler (yordayıcı): (Constant), Biçimsel Olmayan İletişim, Bilgi Paylaşımı, Yönetim Yaklaşımı, İç İletişim

\begin{tabular}{|c|c|c|c|c|c|c|c|c|c|c|c|c|c|}
\hline \multicolumn{14}{|c|}{ Katsayılara $^{\mathrm{a}}$} \\
\hline & & \multicolumn{2}{|c|}{$\begin{array}{l}\text { Standartlanmamış } \\
\text { Katsayılar }\end{array}$} & \multirow{2}{*}{$\begin{array}{c}\text { Standartlaştırılmış } \\
\text { Katsayılar } \\
\text { Beta }\end{array}$} & \multirow{2}{*}{$\mathrm{t}$} & \multirow{2}{*}{$\mathrm{p}$} & \multicolumn{2}{|c|}{$\begin{array}{c}\text { B için \%95 } \\
\text { Güven } \\
\text { Aralığ1 }\end{array}$} & \multicolumn{3}{|c|}{ Korelasyonlar } & \multirow{2}{*}{$\begin{array}{l}\text { Eşdoğrusallık } \\
\text { İstatistikleri } \\
\\
\text { Tolerance }\end{array}$} & \multirow[b]{2}{*}{ VIF } \\
\hline & & B & $\begin{array}{c}\text { Standart } \\
\text { Hata }\end{array}$ & & & & $\begin{array}{c}\text { Alt } \\
\text { Sinir }\end{array}$ & $\begin{array}{c}\text { Üst } \\
\text { Sinir }\end{array}$ & $\begin{array}{c}\text { Sifır } \\
\text { derece }\end{array}$ & Kismi & Part & & \\
\hline \multirow{5}{*}{1} & (Sabit) & 7,627 & 0,555 & & 13,74 & 0 & 6,537 & 8,717 & & & & & \\
\hline & İç İletişim & 0,086 & 0,038 & 0,158 & 2,251 & 0,03 & 0,011 & 0,16 & 0,367 & 0,09 & 0,083 & 0,275 & 3,63 \\
\hline & $\begin{array}{l}\text { Yönetim } \\
\text { Yaklaşımı }\end{array}$ & 0,014 & 0,029 & 0,032 & 0,487 & 0,63 & $\begin{array}{r}- \\
0,043\end{array}$ & 0,071 & 0,332 & 0,02 & 0,018 & 0,314 & 3,185 \\
\hline & $\begin{array}{c}\text { Bilgi } \\
\text { Paylaşımı }\end{array}$ & 0,087 & 0,033 & 0,169 & 2,639 & 0,01 & 0,022 & 0,152 & 0,359 & 0,105 & 0,097 & 0,333 & 3,006 \\
\hline & $\begin{array}{l}\text { Biçimsel } \\
\text { Olmayan } \\
\text { İletişim }\end{array}$ & 0,069 & 0,037 & 0,086 & 1,852 & 0,07 & 0,004 & 0,142 & 0,282 & 0,074 & 0,068 & 0,625 & 1,6 \\
\hline
\end{tabular}

Normatif bağlılık ile iletişim boyutları arasındaki ilişki incelendiğinde;

İletişim boyutları değişkenlerine bakıldığında iç iletişim ve bilgi paylaşımı unsurlarına ilişkin p değerlerinin $<0.05$ olduğu görülmektedir. Bu da bu unsurların devamlılık bağlılığı üzerinde anlamlı bir etkisi olduğunu göstermektedir. Bu durumda;

- "H03. İç iletişimin, normatif bağlllık üzerinde anlamlı bir etkisi yoktur." hipotezi reddedilmiştir.

- "H06. Yönetim yaklaşımının, normatif bağlılık üzerinde anlamlı bir etkisi yoktur." hipotezi reddedilememiştir.

- "H09. Bilgi paylaşımının, normatif bağlılık üzerinde anlamlı bir etkisi yoktur." hipotezi reddedilmiştir.

- "H012. Biçimsel olmayan iletişimin, normatif bağlllık üzerinde anlamlı bir etkisi yoktur." hipotezi reddedilememiştir.

\section{Sonuç ve Tartışma}

Günümüz profesyonel dünyasında insan kaynakları yönetimi, personel yönetimi bakış açısının geride bırakıldığı, insan odaklı stratejik insan kaynağı yönetimidir. Bunun en temel sebebi, bir kurumun başarısında çalışan her bir bireyin etkisinin büyük önem arz ettiğinin anlaşılmasıdır.

Kurumsal bağlılık kavramının öne çıkmasıyla birlikte kurumun hedef ve stratejilerinin kurum çalışanları tarafından benimsenmesinin, bu hedef ve stratejilerinin gerçekleşmesinin sağlanması için en önemli 
adımlardan biri olduğu ve bunun ancak bağlılığı yüksek çalışanlar ile gerçekleştirilebileceği belirtilmektedir. Çalışan bağlılığının yükseltilmesinde ise en önemli araçlardan birinin kurum içi iletişimin olduğu ileri sürülmektedir.

Bu tez çalışmasında bu nedenle, öncelikle Kurum çalışanlarının kurumsal bağlılık düzeyleri ölçülmüş ve buna paralel olarak kurum içi iletişimin bu bağllıktaki önemi yapılan analizlerle belirlenmeye çalışılmıştır. Anket sonucunda ilk olarak ankette yer alan demografik özelliklerden "yaş" ve "kurumda çalışma süreleri" unsurlarının bağlılık üzerinde önemli bir etkisi olduğu görülmüştür. Çalışanların yaşları ve kurumdaki çalışmasüreleriarttıkça kurumsal bağlllıklarının arttı̆̆ı görülmüştür. Analizindevamında, iç iletişim unsurlarının kurumsal bağlılık unsurları üzerindeki etkisi detaylı olarak incelenmiştir. Bu analizlerin sonucunda, bağlllık türleri üzerinde iç iletişim unsurlarının önemli bir etkisi olduğu görülmüştür. Literatürde, "rasyonel bağlılık" veya "algılanan maliyet" olarak da kullanılan devamlılık bağhllığı, çalışanın kurumdan ayrılmanın getireceği maliyetlerin farkında olması anlamına gelmektedir. Bu bağlılık türü kurumlar tarafından ilk tercih edilen bağlılık türü değildir, çünkü genel olarak zorunluluktan kaynaklanmaktadır.

Anket sonucunda, duygusal bağlllık ve normatif bağlılık ile kurum içi iletişim unsurları arasında pozitif yönlü bir ilişki çıkarken, devamlılık bağlılı̆̆ı ile arasında negatif yönlü bir ilişki olduğu görülmüştür. Devamlılık bağlılığı ile ilgili ifadelere bakıldığındaburadaki bağlılık türünün bir tür zorunluluktan kaynaklandığı ve etkili bir iç iletişim sonucunda bu zorunluluktan kaynaklı bağlılığın azaldığı düşünülmektedir.

Diğer bağlılık türlerinden olan duygusal bağhllık, çalışanın kurumuna karşı duygusal bağlılığına işaret eder. Normatif bağhllık da çalışanın ahlaki bir sorumluluk olarak kurumda çalışmaya devam etmek istemesini ifade eder. Bu durum, çalışanın kurumunun kendine iyi davrandığını düşünmesi ve bunun karşılığında kuruma hizmet verme sorumluluğu hissetmesinden kaynaklanır (Çetin, 2004). Yapılan analizlerde, devamlılık bağlılığının aksine duygusal ve normatif bağlılık ile kurum içi iletişm unsurları arasında pozitif yönlü bir ilişki olduğu görülmüştür.

Kurum içi iletişim unsurları ile negatif yönlü ilişkiye sahip devamlılık bağllı̆̆ının yanı sıra duygusal ve normatif bağlılığın kurum içi iletişim unsurları ile pozitif yönlü bir ilişkiye sahip olması, zorunluluktan kaynaklı bağlılığın azalırken çalışanların gönüllü ve ahlaki bağlılığının arttığını göstermektedir. Bu da her kurumun isteyeceği, aidiyet duygusu yüksek, kurumun strateji ve hedeflerini benimseyen çalışan unsuruna sahip olunabileceğini göstermektedir. Bu nedenle Kurumda yapılan analiz açık bir şekilde kurum içi iletişimin pozitif yönde etkisi olacağını göstermektedir.

Özetle, bağllığı yüksek çalışanlar bağllı̆̆g zayıf olanlardan daha katma değeri yüksek çalışanlar olacaktır. İç iletişim ise bu bağlllığ yükseltmekteki en önemli araçlardan bir tanesidir. En basit ifadeyle iç iletişimin hem biçimsel iletişim hem de biçimsel olmayan iletişim gibi bir kurum içindeki tüm iletişim unsurlarından oluştuğunu söyleyebiliriz. Bu, iç iletişimin birbirleriyle konuşan insanlardan çok daha fazla olduğu anlamına gelmektedir. Herhangi bir kurumun can damarı ve herkesin ihtiyaç duyduğu bilgiyi alma şekli olarak tanımlamak yanlış olmayacaktır. Birçok yönden iç iletişim, bir kurumu bir arada tutan tutkaldır. İç iletişim olmadığı bir kurumda, her biri kendi işinde ayrı ayrı çalışan bağlantısız bireylerden oluşan bir iş ortamı oluşacaktır. Ancak her bir bireyin birbiriyle bağlantılı ve uyumlu olarak çalıştığı yerde birlikten gelen başarı her zaman daha çoktur. Bu nedenle, bağlılığı yüksek çalışanlar ve dolayısıyla kurum başarısı için iyi bir ekip, iç iletişim stratejisinin sonuçlarını değerlendirmeli ve sürekli iyileştirmeler yapılmasını sağlamalıdır. 


\section{KAYNAKÇA}

Allen, N. J., \& Meyer, J. P. (1990). The measurement and antecedents of affective, continuance and normative commitment to the organization. Journal of occupational psychology, 63(1), 1-18. Allen, N. Allen, N. J., \& Meyer, J. P. (1993). Organizational commitment: evidence of career stage effects?. Journal of business research, 26(1), 49-61.

Alparslan, Y. M. Kurum içi iletişim diye bir departman var... https://www.cnnturk.com/yazarlar/guncel/yasemin-merih-alparslan/kurum-ici-iletisim-diye-birdepartman-var (Erişim tarihi: 8 Eylül 2014).

Bahar, E. (2012). İletişim. Ankara: Detay Yayıncllk.

Balay, R. (2000). Özel ve resmi liselerde yönetici ve öğretmenlerin örgütsel bağlılığı: Ankara ili örneği. Ankara Üniversitesi, Sosyal Bilimler Enstitüsü, Yayınlanmamış Doktora Tezi, Ankara.

Becker, T. E., Billings, R. S., Eveleth, D. M., \& Gilbert, N. L. (1996). Foci and bases of employee commitment: Implications for job performance. Academy of management journal, 39(2), 464-482.

Blau, G. J. (1985). The measurement and prediction of career commitment. Journal of occupational Psychology, 58(4), 277-288.

Chen, Z. X., \& Francesco, A. M. (2003). The relationship between the three components of commitment and employee performance in China. Journal of vocational behavior, 62(3), 490-510.

Chmielecki, M. (2015). Factors influencing effectiveness of internal communication. Central European Management Journal, 23(2), 24-38.

Çetin, M. Ö. (2004). Örgüt kültürü ve örgütsel bağglllk. Nobel Yayın Dağıtım.

Çöl, G. (2004). Örgütsel bağlllık kavramı ve benzer kavramlarla ilişkisi. ISGUC The Journal of Industrial Relations and Human Resources, 6(2).

DeCotiis, T. A., \& Summers, T. P. (1987). A path analysis of a model of the antecedents and consequences of organizational commitment. Human relations, 40(7), 445-470.

Değer, A. R. Kurum İçi İletişim Nedir? Niye Önemlidir? https://www.brandingturkiye.com/kurum-iciiletisim-nedir-niye-onemlidir/ (16 Kasım 2018)

Demirel, Y., Seçkin, Z., \& Özçınar, M. F. (2011). Örgütsel İletişim İle Örgütsel Vatandaşlık Davranışı Arasındaki İlişki Üzerine Bir Araştırma. Çukurova Üniversitesi Sosyal Bilimler Enstitüsü Dergisi, 20(2), 3347.

Grusky, O. (1966). Career mobility and organzational commitment. Administrative Science Quarterly, 488-503.

Gül, A. G. H. (2002). Orgutsel Baglilik Yaklasimlarinin Mukayesesi ve Degerlendirmesi. Ege Academic Review, 2(1), 37-56.

Gül, H. (2003). Davranışsal bağlılık yaklaşımı ve değerlendirmesi. Celal Bayar Üniversitesi Yönetim ve Ekonomi Dergisi, 10(1), 73-83.

Güllüoğlu, Ö. (2012). Örgütsel iletişim iletişim doyumu ve kurumsal bağhllık. Eğitim Yayınevi.

Gündoğan, T., \& Müdürlüğü, İ. K. G. (2009). Örgütsel Bağlllık: Türkiye Cumhuriyet Merkez Bankası Uygulaması. Türkiye Cumhuriyet Merkez Bankası İnsan Kaynakları Genel Müdürlü̈̆̈̈ Ankara, Uzmanlık Yeterlilik Tezi, Eylül, 23-60.

Gürel, T. (2009). Hizmet İçi Eğitimlerin Kurum İçi İletişim Aracı Olarak Kullanımına Yönelik Bir Öneri. Atatürk Üniversitesi İktisadi ve İdari Bilimler Dergisi, 23(3), 19-34.

Hunt, S. D., \& Morgan, R. M. (1994). Organizational commitment: one of many commitments or key mediating construct?. Academy of management journal, 37(6), 1568-1587.

Lam, T., \& Zhang, H. Q. (2003). Job satisfaction and organizational commitment in the Hong Kong fast food industry. International Journal of Contemporary Hospitality Management. 
F. Bulut - M. Tolon 13/2 (2021) 1255-1272

Meyer, J. P., \& Allen, N. J. (1997). Commitment in the workplace: Theory, research, and application. Sage publications.

Meyer, J. P., Paunonen, S. V., Gellatly, I. R., Goffin, R. D., \& Jackson, D. N. (1989). Organizational commitment and job performance: It's the nature of the commitment that counts. Journal of applied Psychology, 74(1), 152.

Meyer, J. P., Stanley, D. J., Herscovitch, L., \& Topolnytsky, L. (2002). Affective, continuance, and normative commitment to the organization: A meta-analysis of antecedents, correlates, and consequences. Journal of vocational behavior, 61(1), 20-52.

Mowday, R. T., Porter, L. W., \& Steers, R. M. (2013). Employee-organization linkages: The psychology of commitment, absenteeism, and turnover. Academic press.

Özdevecioğlu, M. (2013). Algilanan Örgütsel Destek ile Örgütsel Bağlilik Arasindaki Îlişkilerin Belirlenmesine Yönelik Bir Araştirma. Dokuz Eylül Üniversitesi İktisadi İdari Bilimler Fakültesi Dergisi, 18(2), 113-130.

Powell, D. M., \& Meyer, J. P. (2004). Side-bet theory and the three-component model of organizational commitment. Journal of vocational behavior, 65(1), 157-177.

Tutar, H. (2009). Örgütsel iletişim. Seçkin Yayıncılık.

Tutar, H., \& Yılmaz, M. K. (2012). İletişim.(8. Baskı). Ankara: Seçkin Yayınları. 